China Coup 
The publisher and the University of California Press Foundation gratefully acknowledge the generous support of the Sue Tsao Endowment Fund in Chinese Studies. 


\section{China Coup}

THE GREAT LEAP TO FREEDOM

\section{Roger Garside}

ए UNIVERSITY OF CALIFORNIA PRESS 
University of California Press

Oakland, California

(C) 2021 by Roger Garside

Library of Congress Cataloging-in-Publication Data

Names: Garside, Roger, author.

Title: China Coup : The Great Leap to Freedom / Roger Garside.

Description: Oakland, California : University of California Press, [2021] | Includes bibliographical references and index.

Identifiers: LC C N 2020035735 (print) | LC C N 2020035736 (ebook) | IS BN 9780520380974 (cloth) | IS BN 9780520380981 (ebook)

Subjects: LC SH: Coups d'état-China-Forecasting. | China-Politics and government-2002-

Classification: LCC D S779.46 .G3652021 (print) | LCC D 7779.46 (ebook) | DDC 951.06/2-dc23

LC record available at https://lccn.loc.gov/2020035735

LC ebook record available at https://lccn.loc.gov/2020035736

Manufactured in the United States of America

$\begin{array}{lllllllll}29 & 28 & 27 & 26 & 25 & 24 & 23 & 22 & 21\end{array}$

$\begin{array}{llllllllll}10 & 9 & 8 & 7 & 6 & 5 & 4 & 3 & 2 & 1\end{array}$ 
To all those whose love and friendship have nourished me. 
